УДК 61(477.75)

DOI https://doi.org/10.32838/2663-5984/2020/4.23

\title{
Куриляк В.В.
}

Національний університет «Острозька академія»

\section{ОГЛЯД МЕДИЧНИХ ПРАКТИК ДОБИ СЕРЕДНЬОВІЧЧЯ ТА РЕНЕСАНСУ}

\begin{abstract}
У статті досліджено історію медицини з акиентом на теологічну базу, яка нерозривно межувала з лікарськими практиками в добу Середньовіччя та Ренесансу. Охарактеризовано, що медицина у Візантії базувалася на ращіональних знаннях відомих язичнищьких грецьких $i$ римських лікарів, таких як Гіппократ і Гален. Визначено, що позитивний погляд на медичину, який заклав Іоан Златоуст, залишився в наступні століття. Установлено, що в VI столітті імператор Юстиніан опікувався питанням прачі освічених і кваліфікованих лікарів. Його зусилля сприяли покращенню процесу лікування та догляду за пацієнтами. Акцентовано увагу на особистості Аврелія Августина, який у праиях представляв природу людини крізь призму вчення грецького філософа Платона. Визначено, щз неоллатонізм иього християнського мислителя та його послідовників межував із самопокаранням, яке певною мірою нагадувало вчення гностицизму. Розкрито, щзо позиція християнського мислителя Августина глибоко вплинула на бачення лікарів і полягала в тому, що піклування за духовним станом є важливішим, ніж лікування фізичного здоров'я людини. Також показано діяльність християнських монастирів, які переймалися здоров'ям людей, надаючи їм необхідну медичну допомогу. Виявлено, щзо доба Середньовіччя характеризувалися значними проблемами в гігієні та громадській санітарії. 3 'ясовано, щзо наслідками антисанітарного стану були глобальні епідемії, які під час спалаху забирали життя в мільйонів людей. Розкрито роль відомих єврейських лікарів Мойсея Маймоніда та Балавігнуса, яким у часи пандемії вдалося знизити смертність людей до мінімуму в єврейських гетто. Досліджено стан медицини в епоху Відродження, який відзначився відокремленням медицини від иеекки. Виявлено, що в період Ренесансу в медицину впровадили методи спостереження й експерименту, які сприяли тому, щзо в XVII-XVIII століттях зроблено акиент на необхідності дотримання санітарних правил.
\end{abstract}

Ключові слова: історія медичини, медичні практики, Середньовіччя, Ренесанс.

Постановка проблеми. У зв'язку з пандемією коронавірусу, яка розпочалося в грудні 2019 року, провідні фахівці зосередили увагу на пошуку ефективних методів лікування та вакцинації всього населення землі. Епідеміологічні кризи неодноразово спалахували в добу Середньовіччя та Ренесансу, забираючи мільйони людських життів. Тому звернення наукової уваги на сторінки історії щодо медичних практик доби Середньовіччя та Ренесансу є актуальним напрямом досліджень, особливо в часи світової кризи, викликаної коронавірусною інфекцією.

Аналіз останніх досліджень і публікацій. Історію західної медицини та країн Свропи на теренах України досліджувала низка вчених, таких як С. Верхратський, К. Васильєв, О. Шальнова-Козаченко, А. Грандо та інші. Однак за темою дослідження найближче знаходиться харківчанин, доктор медичних наук, проф. Олексій Опарін, який у низці опублікованих монографій i статей, базуючись на вітчизняних і закордонних джерелах, розкрив і пояснив зв'язок і вплив релігійних і філософських реалій на медичну практику від давнини до Ренесансу, включаючи період Реформації $[1 ; 2 ; 3]$. Також Оксана Драч і Наталія Борисенко, які у 2018 році опублікували навчальний посібник «Історія медицини і фармації (від найдавніших часів до середини XVII ст.)» [4]. У ньому авторки інформативно представили «основні етапи становлення історії медицини і фармації від давнини до середини XVII століття» [4], влучно поєднавши історичний матеріал із джерелами, які описують: «релігійні лікувальні традиції, ставлення суспільства до знахарства, чаклування, замовлянь хвороб, методики лікування і профілактики недугів, гендерний вимір медицини, розвиток медичної освіти тощо» [4]. Дослідження ж медичних практик доби Середньовіччя та Ренесансу влучно доповнить історичну прогалину, оскільки авторка акцентує увагу на поєднанні богословських реалій (домінуючих теологічних поглядів) i «церковної» медицини.

Постановка завдання. Метою дослідження $\epsilon$ окреслення основних медичних практик 
доби Середньовіччя та Ренесансу з акцентом на дослідження впливу на них середньовічних теологічних поглядів.

Виклад основного матеріалу дослідження. На початку зазначимо, що одним із найяскравіших християнських представників раннього Середньовіччя вважають Аврелія Августина (354-430 роки н. е.). Особливість його теології полягає в тому, що він сприймав християнське віровчення через призму філософії Платона. Інакше кажучи, Августин уважав, що життя людини поділяється на два окремі рівні існування: фізичний i духовний. Завдяки впливу вчення Аврелія Августина християни вважали фізичні страждання гідним проявом служіння Богу, оскільки Ісус Христос зазнав їх на хресті.

Неоплатонізм цього християнського мислителя та його послідовників межував із самопокаранням, яке певною мірою нагадувало вчення гностицизму. Останній, у свою чергу, уважався єрессю в християнському середовищі. Гностицизм передбачав, що заради спасіння не потрібно проявляти турботу про тіло, і вчив, що піклуватися треба лише про душу. Отже, філософія Августина щодо гідності людських страждань лягла в основу системи аскетизму. У цьому контексті вчення Августина надавало перевагу зціленню душі, а звернення по допомогу до медицини в лікуванні тіла розглядалося як другорядний фактор [5, с. 48].

Однак у працях Аврелія Августина знаходимо цитати про важливість медицини: «Людина, як ми вважаємо, - це розумна душа, яка використовує земне і смертне тіло. Тому той, хто любить свого ближнього, робить добро частково для його тіла й частково для його душі. Те, що приносить користь організму, називається медициною, а те, що приносить користь душі, - настановою. Але я буду називати тут медициною все, що зберігає або відновлює здоров'я тіла» [6, с. 41].

Також у середні віки створено багато монастирів, у яких людина могла знайти сховище від постійного насилля, потрясінь і нестабільності тогочасного суспільства. Однією з причин таких бід були часті воєнні конфлікти. Однак усамітнення від реального життя хоча й мало свої позитивні сторони, однак суперечило місії Ісуса Христа, яку виконував Він і до якої закликав своїх послідовників. А як відомо: «І ходив Він (Ісус), добро чинячи й усіх уздоровлюючи, кого поневолив диявол, бо Бог був із Ним. І ми свідки всьому, що Він учинив у Юдейському краї та в Єрусалимі» (Дії Апостолів 10: 38-39). Місія Христа полягала не в постійному усамітненні, а в перебуванні серед людей, яким він був готовий робити добро [7, с. 238].

Тому місія монастирів у VI столітті н.е. потребувала реформи, яку в 529 р. н.е. здійснив Бенедикт iз Нурсії (480-543 роки). Він став засновником католицького ордену бенедиктинців, заснувавши в місті провінції Кампала, Італія, монастир, де у високій пошані була ручна праця. У ньому вперше почали піклуватися про слабих, немічних і сиріт. Бенедикт уважав саме це служіння найважливішою справою [7, с. 238], [5, с. 48].

Справу Бенедикта розвинув Кассіодор (487578 роки), відомий державний діяч, який згодом прийняв обітницю чернецтва. Він не лише закликав до догляду та полегшення страждань хворих і тих, хто потребує, а усвідомлював потребу вивчати лікарську справу. Кассіодор почав досліджувати літературні праці Гіппократа, Галена та інших видатних лікарів. Його поради були авторитетними для ченців, і монастирі в наступних століттях для вивчення медицини користувалися книгами, які рекомендував Кассіодор [7, с. 238].

Результатом дуалістичного погляду Аврелія Августина на природу людини стала проблема громадської санітарії. Учення Августина для католицької церкви, яка панувала на Заході, було досить авторитетним. Християни Західної Європи своїм нехтуванням правил гігієни хотіли показати, що вони виступають проти розкоші та розпусного життя язичницьких римлян. Однак разом із цими якостями вони відкидали принцип дотримання тілесної чистоти, який був притаманний римлянам.

Отже, у Середньовіччі нехтування повсякденною турботою про чистоту тіла вважалося чеснотою, тому що людина цим показувала, що ï не приваблюють світські інтереси, вона має прагнення приборкати гріховні тілесні бажання. На відміну від грецької культури, яка пропагувала особисту чистоту, і на відміну від римської цивілізації, яка займалася створенням каналізаційних каналів для забезпечення гігієни на рівні міста, суспільство середніх віків відмовилося від цих позитивних рис здорового способу життя. Корови, свині та інша домашня худоба вільно ходили по вулицях міста. Завдяки антисанітарії блохи та воші, які докучали людям, були звичним явищем. Це все підготувало грунт для приходу епідемій, які періодично розповсюджувалися в Західній Європі [5, с. 49].

3 XIV по XVIII століття в Свропі періодично виникали спалахи поширення чорної чуми, яка ще мала назву «бубонної чуми». Люди нею заражалися через бактерії, які переносяться блохами, a ті, у свою чергу, живуть на щурах. Через укуси 
бліх ці бактерії вражають лімфатичні вузли. Унаслідок цього половина заражених людей помирала від сепсису. Уважається, що від цих епідемій загинула третина населення Європи. Цікаво, що причиною епідемій люди вважали Божу кару або діяльність диявола, оскільки не знали, звідки насправді походить джерело хвороби. А вона виникала внаслідок відсутності особистої та суспільної гігієни [5, с. 49-50].

Перші випадки епідемії - чуми в Західній Європі - стали причиною зацікавленості єврейськими поселеннями (гетто) у європейських містах і принципами їхньої санітарії, оскільки дотримання цих принципів допомогло значно знизити рівень захворюваності й смертності від чорної чуми.

У XIV столітті в місті Страсбурзі жив єврейський лікар Балавігнус. У той період євреї, які жили серед народів, що сповідували католицизм, піддавалися переслідуванням, насмішкам, відчуженню. I лікар цієї національності, навіть якщо він мав високу кваліфікацію, не міг звершувати свою професійну діяльність за межами гетто [8, с. 53-55].

3 метою знаходження методів для боротьби 3 епідемією він пішов навчатися до арабів. На той час араби-мусульмани захоплювали нові території Європи. Однією з позитивних сторін мусульман були високі стандарти санітарії та гігієни, які були невідомі християнським лікарям. Також араби приязно ставилися до євреїв, тому багато видатних лікарів серед мусульманських країн були саме євреями [8, с. 57]. Найбільш відомим із них був Мойсей Маймонід (1138-1204 роки) - великий єврейський філософ Середньовіччя. Поряд 3 іншими науками він цікавився медициною, був знайомий із працями Гіппократа та Галена. Йому належать писемні праці з особистої гігієни, трактати про лікування астми, геморою тощо. Також Маймонід був придворним лікарем одного з арабських візирів [7, с. 230-231].

Щодо Балавігнуса, то він вивчив принципи санітарії, які застосовував сам і яких учив інших людей протягом багатьох десятиліть. Цей лікар навчився цієї науки із санітарних законів книги Левит, із Пятикнижжя Мойсея в поєднанні з теоретичними та практичними напрацюваннями арабів у цій сфері. Зокрема, ідея карантину, якої навчав Балавігнус, грунтувалася на біблійних принципах. Його погляди в санітарії стали фундаментом санітарної науки наших днів [8, с. 57].

Єврейське гетто в Страсбурзі, у якому цей лікар жив, було вільне від бруду та паразитів, якими були наповнені міста Свропи. I коли чорна чума дісталася Страсбурга, то хвороба забирала тисячі осіб у неєврейських районах міста. При загальній паніці Балавігнус почав вводити принципи санітарії в будинках, де жили християни. Відбулася велика кампанія за чистоту помешкань і вулиць. Щури, які розносили чуму, залишили єврейське гетто, шукаючи більш забруднені території. Варто зазначити, що цей лікар не мав сучасного уявлення про мікроби та бактеpiï, однак він чітко усвідомлював пряму причинно-наслідкову залежність між захворюванням і брудом [8, с. $58,60-61]$.

У результаті смертність у гетто становила $5 \%$ порівняно зі смертністю серед неєвреїв. Замість того, щоб відзначити Балавігнуса, паризька колегія лікарів, більшість із яких були християнамикатоликами, виключила його зі своїх лав, уважаючи його шарлатаном. Через те що євреї майже не хворіли на чорну чуму, християни їх звинуватили в тому, що це саме вони навели цю хворобу на жителів міста. Унаслідок цього відбулося жахливе дійство, що досить часто траплялося в ті часи: за підозри та ненависть до цього народу їх піддавали спаленню. Лише через століття санітарні реформи Балавігнуса офіційно визнані наукою й суспільством [8, с. 61, 63, 65-71].

У період раннього Середньовіччя на території Східної Європи у Візантійській імперії існувала боротьба між церковними керівниками та прихильниками філософії Платона - неоплатоніками. У результаті церковні керівники вплинули на імператора Юстиніана (483-565 роки.), який у 529 році закрив Академію Платона, що існувала 3 IV століття до н.е. [9, с. 115-116].

Однак медицина у Візантії, яка трималася на раціональних знаннях відомих язичницьких грецьких і римських лікарів Гіппократа та Галена, збереглася. Позитивний погляд на медицину, що заклав Іоан Златоуст, залишився в наступні століття. Так, у VI столітті той самий Юстиніан опікувався, щоб у лікарнях працювали кваліфіковані лікарі. Ці зусилля привели до покращення процесу лікування та догляду за пацієнтами. Як i раніше, значну роль у роботі лікарень відігравали монастирі [10, с. 150, 152-153, 157-158].

У ХІІ столітті в Західній Європі почав розвиватися конфлікт між Церквою і медициною. Це був період, який історики називають «Ренесанс дванадцятого століття». У той час при збільшенні кількості населення багато людей переселялося в міста. Зростала кількість професій і спеціальностей, які потребують освіти. Збільшувалася кількість шкіл, відбувався розвиток у різноманіт- 
них наукових сферах. Цей рух також торкнувся медицини. Створювалася більш якісна вузькопрофільна медична література. Ці дослідження в методах лікування набували більш світського характеру. Оскільки в середні віки католицька церква намагалася тримати під своїм контролем світогляд на наукове пізнання, то, відповідно, мусила відреагувати на намагання проводити певні дослідження без іiі схвалення [11, с. 13].

Так, у 1130 році церква постановила ченцям вивчати медицину поза територією монастиря. Варто зазначити, що ці закони насамперед були спрямовані проти особистого надмірного збагачення від приватної лікарської практики самих ченців, а не проти медичної науки як такої. Чернець Бернард Клервоський (1090-1153 роки) також виступав проти того, щоб ченці, які захворіли, шукали допомоги в спеціалізованих лікарів. Він говорив, що це «не виглядає релігійно», і радив самим ченцям при хворобливому стані використовувати звичайні лікарські трави [11, с. 14].

Упродовж XII - XIII століть від медицини відокремилася хірургія як окрема дисципліна. I цей поділ зберігся до сьогоднішнього дня. Отже, коли медицина й далі займалася лікуванням хвороб, то хірургія спеціалізувалася саме на травмах і переломах кісток [11, с. 120]. Для перевірки професійної придатності тих, хто називав себе лікарями, потрібно було створити спеціальний акредитаційний орган. Він був створений у 1137 році королем Сицилії Роджером II, який уперше заснував професійну перевірку у сфері медицини. Як журі обрані визнані лікарі, яким допомагали королівські радники. Видана ліцензія давала право людині займатися медициною. А той, хто 3 того часу намагався лікувати без ліцензії, отримував відповідне покарання. Так, у 1267 або 1268 році вперше в історії з'являється посада декана медичного факультету. Ця подія мала місце в Паризькому університеті [12, с. 245].

Говорячи про науковий розвиток Середньовіччя в різних сферах, варто звернути увагу на Фому Аквінського (1225-1274 роки). Він був відомим богословом, який цікавився природою та ii законами, дотримувався погляду на світ із позиції Аристотеля - давньогрецького філософа, тобто не протиставляв фізичний світ духовному. У цьому моменті Фома Аквінський не погоджувався 3 дуалізмом, який проповідував Аврелій Августин. Фома вважав, що Бог є джерелом усієї мудрості, а оскільки Він Творець світу й законів, які в ньому діють, то Бог є основою всіх наук, зокрема медицини [5, с. 55].
Отже, можна зробити висновок, що в Середньовіччі закладений фундамент подальшого розвитку науки, зокрема медицини. Подібно до Фоми Аквінського, багато дослідників того періоду розглядали природу та людський організм як творіння Боже. Тому вони мали інтерес у дослідженні законів Творця. Як результат, шукали методи лікування та запобігання хворобам, від яких часто страждало середньовічне суспільство.

Характеристика медичної практики епохи Ренесансу. В епоху Ренесансу відбувався поступовий відхід різних наук від церковного впливу. Багато теорій, які вважалися аксіомами протягом століть, почали ставитися під сумнів. Дослідники почали звертати увагу не просто на авторитетні книги, а головним у їхніх пошуках став експеримент і спостереження [5, с. 62]. Прикладом нового підходу до науки у сфері медицини XV століття був Василій Валентин. Він уважається засновником сучасної фармацевтики. Саме Василій Валентин завдяки власним спостереженням почав розрізняти хімію як науку та алхімію як псевдознання й умів застосовувати знання з хімії в медицині. Він займався проведенням експериментів, особливо в дослідженні впливу наркотичних речовин.

Ці дослідження були досить успішними, оскільки Василій Валентин уважав, що найкращим засобом для лікування людини є природа. Тому він був переконаний, що завданням лікаря $€$ встановлення того, як працюють природні закони, якими треба навчитися користуватися як засобами допомоги в процесі оздоровлення. Як справжній представник епохи Ренесансу, він був упевнений: безпосереднє дослідження стану пацієнта та впливу на нього тих чи інших ліків $\epsilon$ набагато важливішим, ніж теоретичне знання, яке викладається в книгах. Він навіть наголошував, що даремно звертатися до книжкової інформації в темах, які потребують саме практичного досвіду й аналізу [13, с. 20-21, 364-365].

Також велику роль у медицині в епоху Ренесансу відіграв Філіп Теофраст фон Гогенгайм (1493-1541), який вибрав собі псевдонім Парацельс. Ця назва взята 3 метою порівняти й поставити себе над римським лікарем Цельсом. Парацельс був лікарем і вченим і багато знав про склад і будову різних медпрепаратів. Парацельс створив багато нових ліків на основі спостережень як фізіологічних процесів в організмі, так і процесів перебігу хвороби і помічав їх подібність. Він поставив під сумнів давню теорію Гіппократа та Галена, що здоров'я людського організму залежить від балансу чотирьох субстанцій рідин, які 
знаходяться в тілі. Цей сумнів набув розвитку 3 тієї причини, що спостереження за станом хворих у його лабораторії показували результати, які суперечать цій теорії. Тому Парацельс надалі визнавав наявність цих субстанцій в організмі, однак не надавав їм головної ролі у відновленні здоров'я. Під сумнів були поставлені традиційні медичні погляди щодо описання механізму розвитку різних захворювань [14, с. 154-155].

Парацельс застав час початку Реформації в 1517 році проти надмірних зазіхань влади папського Риму та боротьби протестантизму за існування. 3 огляду на ці обставини, противники одного 3 реформаторів медицини назвали «Lutherus medicorum», 3 латинської «Лютер лікарів». Подібно, як Лютер відкидав столітні традиції католицької церкви, так і Парацельс піддавав сумніву тисячолітні традиційні погляди у сфері медицини [15, с. 9-10].

Подібно до Василія Валентина, засновник медичної хімії Ян Баптист Ван Гельмонт (1579-1644 роки) зробив великий внесок у розширення сфер використання лікарських засобів. Також для нього критерієм істини в медицині були спостереження, а не давня традиція або чийсь авторитет. Вагомість впливу та вклад у медицину цих трьох лікарів відчувається від епохи Ренесансу й аж до сьогодні [13, с. 365].

У XVII столітті вклад у розвиток медицини внесено Томасом Сіденхемом (1624-1689 роки). Він був англійським лікарем, його ще називали «англійським Гіппократом». Т. Сіденхем підкреслював необхідність особистого спостереження за хворими людьми та забезпеченням для них усебічного догляду. Він був одним із тих лікарів, які наражали власне здоров'я й життя на небезпеку, коли лютувала велика чума в Лондоні в 1660-х роках, опікуючись тими, хто заразився та помирав. Він виступав за дотримання особистої гігієни [16].

XVIII століття століття характеризувалося розвитком християнських лікарень. Особливістю цього руху було те, що ініціаторами створення лікарень були представники протестантизму. Серед них були англійські проповідники Джон Уеслі і Джордж Уайтфілд. Цей історичний період називають ще «епохою лікарень». Там лікували хворих людей, які не мали достатньо коштів, щоб оплатити своє лікування. Робота лікарень підтримувалася за рахунок благодійних внесків меценатів. Цей рух охопив Західну Свропу, у резуль- таті чого проповідник Джон Уеслі стверджував: «Чистота справді знаходиться поряд із благочестям» [16]. Тому можемо сміливо стверджувати, що в період Середньовіччя богослоська думка не сприяла формуванню позитивного ставлення до медичних практик, хоча церква через монастирі надавала необхідну медичну допомогу. Однак через розрив, який відбувся між медициною та церквою в період Ренесансу й Реформації, медицина вийшла на рівень застосування раціональних практик, створивши пощитивне підгрунття для формування сучасної медичної науки та практики.

Висновки. Отже, підводячи підсумки дослідженню, зазначимо, що в добу раннього Середньовіччя авторитетною була постать Аврелія Августина. Він дивився на людську природу крізь призму вчення грецького філософа Платона. Августин уважав, що життя людини поділяється на фізичний і духовний рівні. На думку мислителя, необхідно піклуватися про свій духовний стан заради спасіння для вічності, а турбуватися про фізичне тіло не потрібно. Такі переконання Августина сприяли тому, що звернення за допомогою до лікарів почали вважати незначущою справою. Проте фізичними потребами страждальців переймалися в монастирях, котрі знаходилися під впливом Бенедикта 3 Нурсії та Кассіодора. Водночас доба Середньовіччя відзначалася великими проблемами в гігієні та громадській санітарії. Наслідком цього стали епідемії, які час від часу спалахували і Європі й характеризувалися загибеллю мільйонів людей. У період середніх віків відомими єврейськими лікарями були Мойсей Маймонід і Балавігнус, їм удалося зберегти життя багатьом мешканцям єврейського гетто в Страсбурзі завдяки дотриманню санітарно-гігієнічних законів, записаних у книзі Левіт. В епоху Відродження продовжилося відокремлення медицини від церкви. У той період зародилася фармацевтична галузь у іiі сучасному розумінні. Серед iii тодішніх представників - Василій Валентин, Ян Баптист Ван Гельмонт, Парацельс. Вони та інші тогочасні відомі постаті наголошували на важливості спостереження за станом перебігу хвороби в людини задля пошуку кращого методу лікування. Крім цього, у XVII - XVIII століттях акцентувалося увага на необхідності дотримання санітарних правил, прихильниками яких, зокрема, були протестантські проповідники.

\section{Список літератури:}

1. Опарин А.А. Медицина средних веков. Религия. Философия. Суеверия. Східноєвропейський журнал внутрішньої та сімейної медицини. 2015. № 1. С. 86-95. 
2. История древней и средневековой медицины. Харьков : Факт, 2017. 784 с.

3. Опарин А. История медицины эпохи Возрождения и Реформации. Харьков : Факт, 2018. 416 с.

4. Драч О.О., Борисенко Н.М. Історія медицини і фармації (від найдавніших часів до середини XVII ст.) : навчальний посібник. Черкаси : видавець Чабаненко Ю.А., 2018. 244 с.

5. Kuta A.K. The Judeo-Christian Influence on Western Medicine: The Rise and Decline of Cultural Christian Ethics in the Practice of Medicine. Virginia Beach, 2010. $112 \mathrm{c}$.

6. Augustinus A. The Catholic and Manichaean Ways of Life. Washington, DC : Catholic University of America Press, 1966. $150 \mathrm{c}$.

7. Buck A.H. The Growth of Medicine from the Earliest Times to About 1800 New Haven : Yale University Press, 1917. $582 \mathrm{c}$.

8. Atkinson D. Life sketches of great physicians. New York : Vail-Ballou, $1922.159 \mathrm{c}$.

9. Shepard J. The Cambridge History of the Byzantine Empire (500-1492). New York : Cambridge University Press, 2008. $1207 \mathrm{c}$.

10. Miller T. The birth of the hospital in the Byzantine Empire. London : Johns Hopkins University Press, 1997. $288 \mathrm{c}$.

11. Siraisi N. Medieval and Early Renaissance Medicine. Chicago : University of Chicago Press, 1990. 249 c.

12. Compayre G. Abelard and the Origin and Early History of Universities. New York : Charles Scribner's Sons, $1893.315 \mathrm{c}$.

13. Walsh J. Old-Time Makers of Medicine. New York: Fordham University Press, 1911. 446 c.

14. Sigerist H. Civilization and Disease. New York: Cornell University Press, 1945. 255 c.

15. Weeks A. Paracelsus. Speculative Theory And The Crisis of The Early Reformation. New York: State University of New York Press, 1997. 238 c.

16. Beal-Preston R. The Christian Contribution to Medicine. URL: https://www.cmf.org.uk/resources/ publications/content/?context=article\&id=827 (дата звернення: 15.05 .2020 ).

\section{Kuryliak V.V. HISTORY OF MEDICAL PRACTICES OF THE MIDDLE AGES AND RENAISSANCE}

The article examines the history of medicine with an emphasis on the theological basis, which inextricably bordered on medical practices in the Middle Ages and the Renaissance. It is described that medicine in Byzantium was based on the rational knowledge of famous pagan Greek and Roman physicians, such as Hippocrates and Galen. It is determined that the positive view of medicine, laid down by John Chrysostom, remained in the following centuries. It is established that in the VI century, Emperor Justinian took care of the work of certified and qualified doctors. His efforts have improved the treatment and care of patients. Emphasis is placed on the personality of Aurelius Augustine, who in his works represented human nature through the prism of the teachings of the Greek philosopher Plato. It is determined that the Neoplatonism of this Christian thinker and his followers bordered on self-punishment, which to some extent resembled the teachings of Gnosticism. It is revealed that the position of the Christian thinker Augustine deeply influenced the vision of doctors, and was that the care of the spiritual condition is more important than the treatment of physical health. However, the article also shows the activities of Christian monasteries, which cared about people's health, providing them with the necessary medical care. It was found that the Middle Ages were characterized by significant problems in hygiene and public sanitation. The consequences of the unsanitary situation were found to be global epidemics that claimed the lives of millions of people during the outbreak. The role of the famous Jewish doctors Moses Maimonides and Balavignus, who managed to reduce human mortality to a minimum in the Jewish ghettos during the pandemic, is revealed. The state of medicine in the Renaissance, which was marked by the separation of medicine from the church, was studied. It was found that during the Renaissance, methods of observation and experiment were introduced into medicine, which contributed to the fact that in the XVII - XVIII centuries the emphasis was placed on the need to comply with sanitary rules.

Key words: history of medicine, medical practices, Middle Ages, Renaissance. 